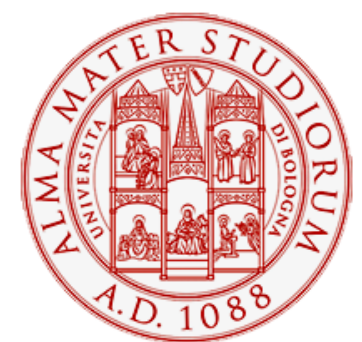

Alma Mater Studiorum - Università di Bologna DEPARTMENT OF ECONOMICS

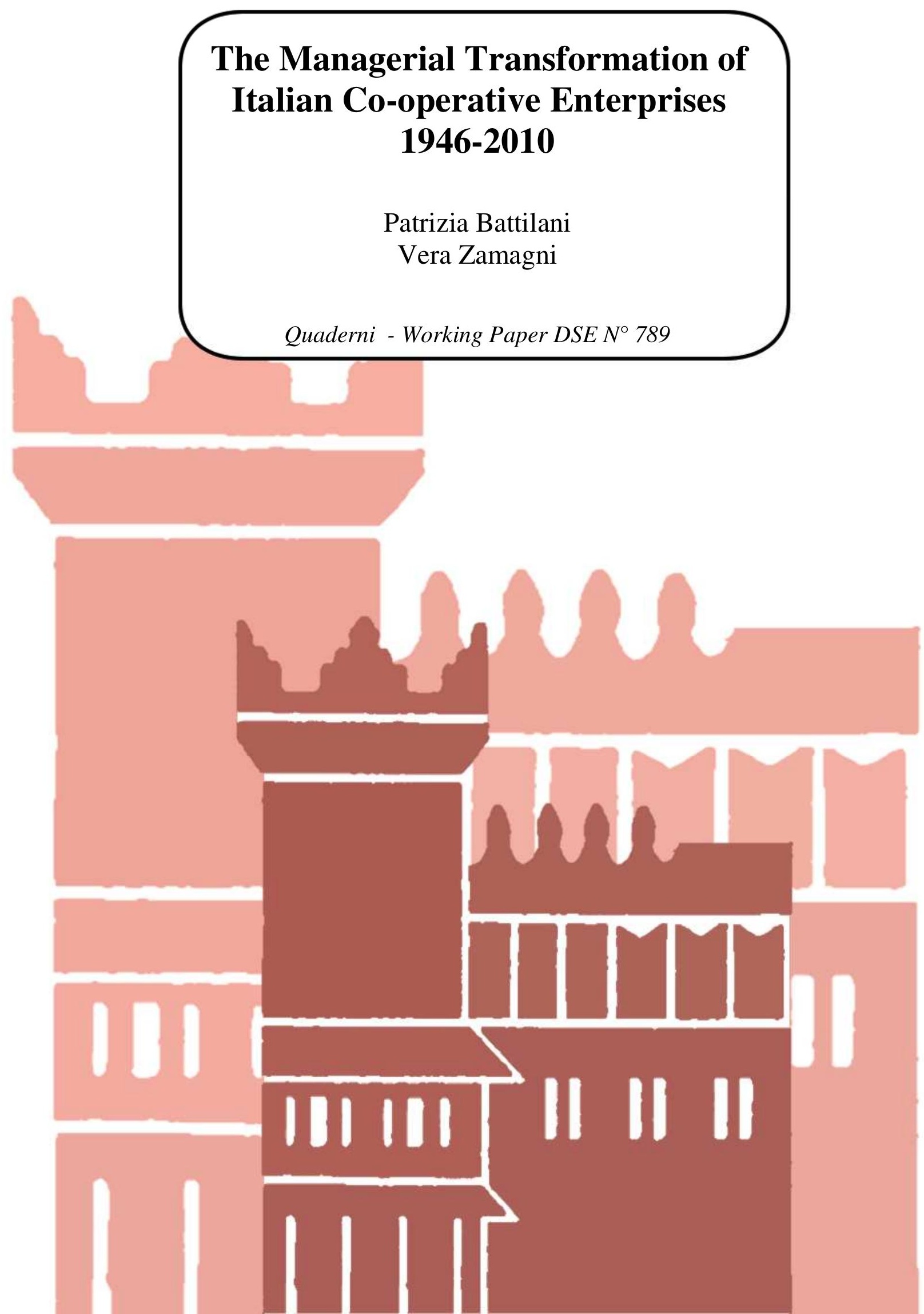




\title{
The Managerial Transformation of Italian Co-operative Enterprises
}

1946-2010

Patrizia BATTILANI, Department of Economics, University of Bologna, Bologna, Italy

Vera ZAMAGNI, Department of Economics, University of Bologna, Bologna, Italy

\section{The Managerial Transformation of Italian Co-operative Enterprises}

\section{6-2010}

\begin{abstract}
The Italian co-operative enterprises have prospered in the last thirty years in various sectors. In this essay we analyze the role played by managerilization in allowing Italian co-ops to compete nationally and internationally with capitalist enterprises. On the basis of a substantial set of company histories and managers interviews, we have built a three generations model of co-ops managers, which shows the changes that have allowed co-ops to become fully equipped with managerial skills. The strong leadership of umbrella organizations, the inner careers of most managers and legislation have been instrumental in avoiding demutualization, the killer of co-ops in many other countries.
\end{abstract}

Key words: Co-operative enterprises, Managers selection, Business history

Jel classification: $\mathbf{N 8 0}$

\section{Introduction}

Is a "co-operative manager" different from a manager tout court? In 2003 David Griffith addressing this question highlighted the importance for executives to be fully aware of the co-operative specific commitments and skills. The debate about cooperative managers distinctive status emerged in the first decade of the new millennium in the wake of de-mutualization of many co-operatives in the United States and in other countries (Battilani, Schroeter 2011). According to many observers, managers had been playing a leading role in the conversion of co-operatives into capitalist enterprises. For instance, in 2003 Tayler in his research on the demutualization of UK building societies 
concluded that in many cases management played an active role in demutualizing their societies. Based on this evidence, he suggested demutualization to be inevitable when management does not defend mutuality. Cook et al. (2001) and Stephens (2001) gave several examples of senior managers making large short term financial gains as a result of demutualization, including payouts or increased salaries in the new enterprise. Finally, Hind claimed in 1999 that in the later stages of their life cycle, agricultural cooperatives, having become larger and more market oriented, were stimulated to satisfy the aspirations of managers, rather than those of farmers. Thus the main problem for the survival of co-ops seemed to have become the conflict between managers and members.

For anyone with a little familiarity with the history of co-operative enterprises, it is easy to appreciate the distance to this debate that characterized the seventies and eighties. At the time, scholars preferred to concentrate on the lack of management skills within co-operatives and the impossibility of the latter to attract good executives from investor oriented enterprises (IOE), for a variety of reasons. The first reason is the nature of co-operative enterprises, in which managers are chosen by members. According to this view, elected management will always lack authority to impose discipline upon their constituency (Alchian and Demsetz, 1972). Secondly, we have to mention the social and cultural background of members, who prefer the family-like atmosphere of small companies to the hierarchical organization of big business ( $\mathrm{J}$. Rothschild-Whitt, 1979). Another reason is given by the egalitarian instances that affected managers' remuneration and therefore made co-operative unattractive for the IOE executives. Over the past three decades, all the previous concerns related to the lack of proper management in co-ops have vanished, being replaced by a completely new problem, the lack of co-operative culture among the new managers. Actually, the 
former line of analysis (lack of appropriate management) is still important in some developing countries, like India and the African states.(Satgar and Williams 2008; Nkhoma and Conforte 2011; Jan and Trehan 2009-2010)

As economic historians, we cannot avoid enquiring what has produced such a radical change in the study of co-operative management, a question that we will address focusing on the Italian case. Italy is among the advanced countries having experienced in the last 30 years a successful growth of co-operative enterprises, which have been able to modernize and compete with national and international capitalist enterprises. The explanation of this positive performance is complex and includes legislation, which has allowed co-ops to strengthen their capital assets ${ }^{1}$; culture, which has induced many Italians to prefer co-operatives to capitalist enterprises ${ }^{2}$; market structure, which is largely made up of small businesses not giving rise to large concentrations of capitalist economic power; managerialization. In this essay we will concentrate on a discussion of this last component of the Italian co-ops success, availing ourselves of the large number of histories of companies and of their networks we have produced in the past years.

The essay will first give an overview of the evolution of Italian co-ops, to clarify which type of growth has taken place; in the second section we will analyze the changes in managers' selection and training and their impact on managerial practices inside coops; in the third section, we develop three examples of the role played by managerial

\footnotetext{
${ }^{1}$ Co-ops have received a specific mention in article 45 of our post II world war Constitution, which was approved in 1947 and is still in force today.

${ }^{2}$ It is interesting to note that co-ops were supported by all the Italian cultural matrices, socialist (and communist later), catholic and liberal. The liberal matrix was present in a party which, being in favour of changing the institutional setting of the Italian State into a republic, was named "republican", keeping that name even after the monarchy was abolished in 1946.
} 
practices in the life of major co-ops, to give flesh to our typology, with an attention to make use of co-ops acting in different economic sectors. The final section will draw a few conclusions.

\section{Evolution of the Italian co-operative enterprises after World War II}

The study of Italian co-operative enterprises history has been made difficult by a dearth of macrodata, which we have tried to fill with ad hoc research, without being able to set up a comprehensive overall long term picture yet. The results of our efforts to the present day have appeared in a recent publication (Battilani and Zamagni, 2010) and, although many gaps are still left, they are unequivocal in locating substantial growth since the 1970s, both in number of co-ops and in their economic strength. From some 10,000 co-ops in 1951 , which remained stable until 1971, we have 66,000 co-ops today; from $2 \%$ of total employment in 1951, still at that level in 1971, we are today at 7\%. A detailed picture of the economic situation of Italian co-ops in 2009 can be seen in table 1. We have put together the accurate data of three out of the five umbrella organizations (the other two are pretty small and not much willing to supply information). As in Italy it is possible to use the co-operative form of enterprise without being part of any umbrella organization, we had to produce a guess of the economic features of these practically unknown co-ops for completeness, keeping in mind that no important co-op is using this option, because umbrella organizations provide many services to their associates. The guess is a very conservative one, so the total cannot be overstated. 
Table 1. The Italian cooperative movement in $2009^{\mathrm{a}}$

\begin{tabular}{|l|r|r|r|r|}
\hline & $\begin{array}{l}\text { No. of } \\
\text { co-ops }\end{array}$ & $\begin{array}{l}\text { Turnover } \\
\text { (billion Euro) }\end{array}$ & Members & \multicolumn{1}{l|}{$\begin{array}{l}\text { Employment } \\
\text { (direct) }\end{array}$} \\
\hline Legacoop & 15,500 & 57 & $8,550,000$ & 486,000 \\
\hline Confcooperative & 20,300 & 61 & $3,127,000$ & 535,000 \\
\hline AGCI & 6,900 & 7 & 388,000 & 71,000 \\
\hline UNCI & $7,82^{\mathrm{b}}$ & $2^{\mathrm{c}}$ & $150,000^{\mathrm{c}}$ & $70,000^{\mathrm{c}}$ \\
\hline Unicoop $^{\mathrm{d}}$ & $1,000^{\mathrm{c}}$ & $0.2^{\mathrm{c}}$ & $5,000^{\mathrm{c}}$ & $10,000^{\mathrm{c}}$ \\
\hline Not belonging & $15,475^{\mathrm{e}}$ & $1.5^{\mathrm{c}}$ & $90,000^{\mathrm{c}}$ & $100,000^{\mathrm{c}}$ \\
\hline Total & $\mathbf{6 6 , 0 0 0}$ & $\mathbf{1 2 9}$ & $\mathbf{1 2 , 3 1 0 , 0 0 0}$ & $\mathbf{1 , 2 7 2 , 0 0 0}$ \\
\hline & & & & \\
\hline
\end{tabular}

Source: from official data supplied by the umbrella organizations. The total number of co-ops comes from the Central Office of the Chambers of commerce and includes farmers and fishermen co-ops.

Notes: ${ }^{\text {a }}$ Popular banks are excluded, because they are not legislatively recognized as co-ops on the basis of article 45 of the Constitution, although they still have members with less than .5\% of capital and the democratic rule one head one vote. In 2009 they number 97, with 1.16 million members, 83,740 employees and a market share of $15 \%$.

${ }^{\mathrm{b}} 2004$

${ }^{\mathrm{c}}$ estimate

${ }^{d}$ it is the most recently formed umbrella organization, registered 7/05/2004

${ }^{\mathrm{e}}$ The number has been produced as a residual, subtracting the other rows from the total

The important piece of information needed to be able to comment table 1 concerns the five umbrella organizations. They are not divided according to sectoral specialization, as in other countries, but according to a different ideological origin. Legacoop (born in 1886) was based on the socialist (later communist) ideology; Confcooperative (born in 1919) on the catholic inspiration; AGCI (born in 1952) gathered co-operators of liberal faith; UNCI (1975) was a splinter from Confcooperative, Unicoop (2004) is too recent to share in this sort of characterization (and not much is known about it). The latest piece of news to this regard is that the three strongest organizations have formed in 2011 the Italian co-operative Alliance (Alleanza delle Cooperative Italiane, $A C I$ ) with the aim of overcoming divisions (no longer understandable, as a result of the recent de-ideologization of public life) and of rationalizing activities. ACI represents today the strength of the Italian co-operative movement. Among the three organizations, while Legacoop and Confcooperative are of 
similar size in economic terms, Legacoop boasts the largest number of members, because it associates the overwhelming share of consumer co-operatives.

There are three additional features of Italian co-operative enterprises that should be highlighted to understand the reasons of the solidity of the movement: 1) sectors; 2) size of enterprises; 3) networks. As for sectors, Italian co-operatives are present in all sectors of the economy, including manufacturing ${ }^{3}$, with a leadership in retailing (with two brands COOP and CONAD covering $1 / 3$ of the organized grocery market ${ }^{4}$ ), in the construction industry (with three co-ops among the 10 largest Italian companies and a consortium CCC which is the largest Italian general contractor), in catering (CAMST), in facility management (MANUTENCOOP), in insurance (the third largest Italian company UNIPOL is a j.s.c,. but fully controlled by co-ops). Co-ops also have a leadership in the delivery of social services, because local authorities have outsourced most of the services, but also hold an important presence in other services (logistics, transportation, porterage, media, tourism) and in banking, where the group of 422 credit unions holds $8 \%$ of market share. Finally, co-ops have an extremely important presence in the food industry, where they have a market share of $1 / 4$, and in agriculture, where coops have a participation of $35 \%$ in Gross Saleable Production. It must be added that, at the exception of social co-ops, market shares in the North of the country are larger than the average, because traditionally co-operation is not well established in the Southern

\footnotetext{
${ }^{3}$ Manufacturing is the "missing" sector for co-ops in the world, at the exception of the famous Mondragon Co-operative Corporation and of some medium size Italian co-ops, like SACMI, which is specialized in machinery for the production of ceramics and machinery to bottle beverages.

${ }^{4}$ Retail Co-ops have been excellent in organizing their wholesale level, which services also other retailers, controlling $40 \%$ of the whole Italian grocery market.
} 
regions, confirming that Italian co-ops flourish in the economically strongest areas of the country, not in the poorest ones.

The size of Italian co-ops is also remarkable: co-ops have on average an employment larger than j.s.c. (17 employees per co-op against 14 employees per j.s.c. in 2001, the latest census data available). Being a well known feature of the Italian economy its small size of business, which had a tendency for j.s.c. since the 1970 s to become on average even smaller (moving from 71 to 14 employees between 1971 and 2001), co-ops have not followed in this trend, keeping their average size practically constant within the same dates, but strengthening their big companies, which today account for $10 \%$ of all the largest Italian companies ( $>500$ employees). The evolution of the largest co-ops 1971-2001 can be seen in table 2; after 2001, the trend of consolidation of co-ops has strengthened (S. Zamagni and V. Zamagni, 2010).

Table 2. Cooperative enterprises with 500 or more workers*

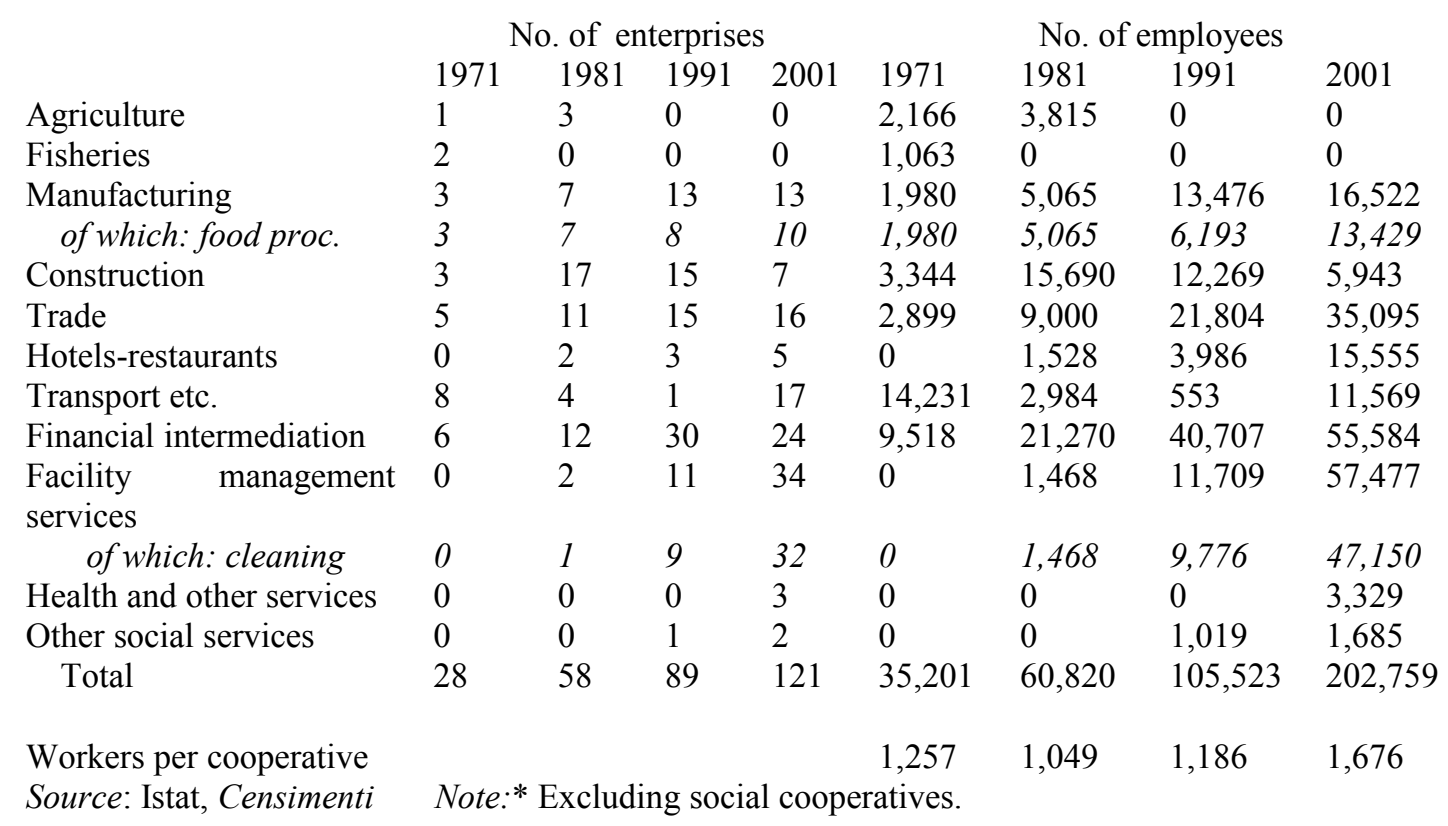


One final feature of Italian co-ops is their tight networking, which we have studied in some detail (T. Menzani and V. Zamagni, 2010). The first instrument to build networks was the consortium, available already since the beginning of the $20^{\text {th }}$ Century. Originally, consortia were horizontal networks, that allowed co-ops to pool their resources to be able to carry on larger activities, while still practicing direct democracy in their small companies. Later on, consortia developed also other types of networks, but, above all, paved the way to mergers and therefore greatly helped the increase in the size of co-ops. In the latest 30 years, another instrument was used, i.e. the formation of co-operative groups, encompassing also joint stock companies fully owned or controlled by co-ops. Groups tend to be formed to control an area of business in its various components. But the Italian co-operative networking is much more than consortia and co-operative groups. Umbrella organizations, beside formal representation of the movement, form sectoral associations, which discuss and implement long term strategies, and local associations, which preside over local opportunities; they provide financial and professional services and make a strategic use of a fund dedicated to the development of co-operation ${ }^{5}$. They sometime play a role of lender of last resort.

It is now clear that the management of such a complex system of enterprises had to develop appropriate managerial capabilities, to be able to sustain growth. How these capabilities were achieved is the central issue of the present article, to which we now turn.

\section{Change in managerial practices: three generations of co-operators}

\footnotetext{
${ }^{5}$ The fund is formed with $3 \%$ of the profits of the associated co-ops and is managed centrally by each umbrella organization.
} 
As we have already mentioned in the introduction, the setting up of appropriate managerial hierarchies couldn't be given for granted in cooperative undertakings. Indeed, for all the seventies and eighties the theoretical and empirical research had identified a key weakness in the low educational levels and minimal training of cooperative members and managers. However, co-operatives could enjoy at least of one advantage over the most widespread form of enterprise in Italy, namely family enterprise: they were not transferring command of the company to sons and daughters.

These issues have been addressed in various ways in the business histories published over the last two decades (Fabbri 1995, Battilani 1999, Zamagni 2002, Bertagnoni 2004, Leonardi 2005, Battilani and Bertagnoni 2010; Battilani, Bertagnoni, Vignini 2008; Battilani 2011, Zamagni, 2011), but no long-term vision had been worked out in the past locating the turning points. In this section we offer a first attempt to build a model of co-op managers evolution, on the basis of a plurality of sources: interviews (collected partly by ourselves and partly by others researchers); documents stored in the company archives at the Documentation Centre for Cooperation in Bologna; research carried by the Bologna University group of business historians.

A new dataset of 109 cooperative managers born between 1883 and 1970 has been put together. For each manager, we collected the following information: date of birth, formal education, career path, ideological background as well as the role played in co-ops during their working life. Overall, a dozen business history of co-operatives, consortia and groups, have been taken into consideration: the Consumer co-ops (comprehensive of the wholesale co-op and of some of the nine big co-operatives active today); Granarolo (number one in the dairy sector); the CNS, National consortium of service cooperatives (number three in facility management); the CTA, Food Transport 
Co-operative (a middle size co-op of truckers), Coind (a co-operative that operates as a co-packer); CCC and CMC, (two of the Italian companies leader in the building sector); and CAMST (leader in catering). Of course this sample is not representative of the entire co-operative world, but it allows the identification of the strategies adopted by most successful co-operatives. In other words, it allows to identify what we might call the good practices in the training and selection of managers. Regarding the territorial distribution, the sample is unbalanced on the reality of Emilia Romagna, but this is partly a consequence of the high concentration of large co-operatives in that region. From the sectoral point of view, however, the sample is fairly representative. Only the financial sector and social cooperatives were not included. Finally, regarding the umbrella organizations, all co-ops in the sample either always adhered or at some point in their life joined Legacoop. Up to now no information of this type is available for cooperatives connected with the other Italian apex organizations.

Our managers dataset permits us to identify three generations, each of which has a strong characterization in terms of formal education and ideological background, as it can be seen in the summary table $3^{6}$. The first generation is represented by those born before 1928, who played a leadership role between 1947 and 1954. This is a group without formal education: many of them did not get beyond primary school, some not

\footnotetext{
${ }^{6}$ It is important for our research to distinguish between generation and cohort. The cohort is an aggregate of individuals who share a given time period. The generation is something more and different, as it assumes a common experience (L. Mannheim 1928; N.B. Ryder and Charles F. Westoff, 1965).
} 
Table 3. Co-operative managers dataset

\begin{tabular}{|l|l|l|l|l|l|l|}
\hline Year of birth & number & $\begin{array}{l}\text { Former } \\
\text { partisans }\end{array}$ & $\begin{array}{l}\text { Work } \\
\text { experiences } \\
\text { outside the } \\
\text { cooperative } \\
\text { movement }\end{array}$ & $\begin{array}{l}\text { Primary } \\
\text { school }\end{array}$ & $\begin{array}{l}\text { Secondary } \\
\text { school }\end{array}$ & $\begin{array}{l}\text { Tertiary } \\
\text { school }\end{array}$ \\
\hline Before 1928 & 28 & 22 & 19 & 13 & 10 & 3 \\
\hline $\begin{array}{l}\text { Between } \\
\text { 1928-1944 }\end{array}$ & 45 & 0 & 17 & 15 & 24 & 6 \\
\hline $\begin{array}{l}\text { Between } \\
1946-1970\end{array}$ & 36 & 0 & 16 & 0 & 12 & 21 \\
\hline total & 109 & 22 & 52 & 26 & 49 & 29 \\
\hline
\end{tabular}

Source: Battilani and Bertagnoni archive of oral history - File "Cooperative managers"; V. Zamagni database.

even completed it. Most of them had participated in the Resistance against the fascist regime, and this experience became the key element of characterization of their generation. They embraced the idea of a comprehensive transformation of society that led them to adhere to the Left parties, look with sympathy to the unions and work in the co-operative movement.

Most of them had already matured some kind of work experiences before being appointed by a co-op or before becoming the founding members of a co-op. However, they built their career entirely within the co-operative movement, but not within the same undertaking. Very often this generation of managers moved from one co-operative to another. Equally common is the working experience in some branches of the umbrella organization or in the sectoral associations. Their career path is usually the following: they start working very young in a co-operative as assistant, clerk, porter, bricklayer (if they have a secondary school certificate their first work could be as assistant accountant), then little by little they become executives in small co-operatives or consortia. On the occasion of mergers, some of them can become the chief executive 
of the new undertaking. To sum up, the first post-war generation of managers was selftaught, grew up within the co-operative world, shared a common set of values and the same vision of the world.

The recruitment of managers from IOEs was not even contemplated. At that time co-ops and investor oriented enterprises were much more than a different form of undertaking; they were two separate worlds. This is why during the eighties, when the Italian historians tried to explain the 1950-1970 co-operative stagnation, they pointed their finger against the ideological attitude of co-operative members and managers, in particular within Legacoop, the leftist umbrella organization. The fact of seeing the cooperative movement as part of a broader process designed to overturn the capitalist economy was deemed responsible for the lack of a proper entrepreneurial culture.

However, the lack of formal education didn't prevent this generation of managers to adopt significant innovations within the undertakings they staffed. Usually they compensated for the lack of formal education with a great spirit of initiative and in the middle phase of their career they were also able to introduce important changes in accounting practices or to initiate innovative experiences on the marketing side. Indeed, the updating of accounting standards started already in the mid-fifties. Since 1956 both Legacoop and the Consumer co-operatives national association (ANCC) tried to stimulate the introduction of these innovations in several ways, also by promoting them in the co-operative journals.

"ANCC instructed its officers to spread the use of the budget sheet, at least in middle and large size co-operatives, as a tool to plan and control both business and social activity... It was necessary for this purpose to provide a budget model which, while conforming to the accounting standard, was well suited to the needs and specificity of a co-operative undertaking. ANCC has therefore prepared a form that consumer cooperatives will have to fill in...In this way it will be possible to remove and minimize 
the drawbacks and failures of management, giving managers a more timely vision of the key business issues and moving a step forward in managing co-operatives... "( F. di Marco 1956).

The chart of accounts "in the first place allows to detect at any time the economic and financial situation and, by keeping non-accounting operations at a minimum, to quickly analyze the management performance and evaluate the different cost components. Secondly, it allows to arrive at the yearly and semester financial statements that show the overall situation of the company." (Gherpelli 1956).

Granarolo is a very good example of innovation in marketing strategy. The company was set up in the late fifties by sharecroppers and small farmers in order to improve the yield of the milk they produced. For over thirty years, the co-operative was run by the same men who had created the conditions for its birth (Franco Migliori, Otello dalla Casa, Nerio Nobili). None of them had a secondary school certificate. Despite this, at the end of the sixties they adopted a very original and aggressive marketing strategy that permitted the co-op to beat the investor owner enterprises' competition in the local market. Peppino Ortoleva called it "the Italian way to marketing" (Ortoleva 2004). Because competitors had more capital and therefore could make greater investments in advertising and marketing, Granarolo executives adopted a series of low cost ways to introduce their brand to customers. In 1959 their adversiting campaign included the printing of 90.000 promotional brochures, the recording of commercials for cinemas and the painting of the Granarolo logo on the milk transport vans. However, the truly innovative idea was to appeal to social solidarity: they organized promotional meetings among the members of all the socialist inspired associations, co-operatives and even political parties of the left in the province. Besides, always with a view to strengthening the relationship with the surrounding area, the 
Granarolo managers invited school children and workers of neighboring companies to visit the plants and brought milk to the workers on strike (Interview with Franco Migliori). When in the early seventies the co-op began to expand in the markets of other provinces, the same marketing strategy was chosen (Granarolo Archive, Minutes of the Board of Directors).

Even if most of them were self-taught, there were also exceptions. As shown in Table 1, three executives of that age were graduate. Most of them were engineers or surveyors that had built their careers in the CCC. The CCC founded at the beginning of XX century experienced a first development in the interwar period surviving to fascist takeover and even the WWII. Since the earliest days, the consortium began to recruit graduates because in the building sector engeneerings or surveyors were necessary to sign the projects. The graduates were recruited during the Fascist period and kept working in CCC even at the end of World War II, as they had been able to keep distance from the prewar regime (Fabbri 1995).

In conclusion, the "Renaissance" of co-operatives that followed the second world war in Italy was driven by two distinct group of managers: the "young", who came for the partisan struggle, and " the old", who had been recruited in the previous decade, but were able to keep distance from the fascist government. The latter often had a higher level of formal education than the former.

The second generation is represented by those born between 1928 and 1944 . Usually they started to work in a co-operative after 1950 and became executives during the seventies. For reasons of age they didn't take part in the Resistance, but continued to be united by the same values of the previous generation and strengthened their solidarity and common vision through membership of the Italian left. From our 
perrspective, the most interesting feature is that this generation included a higher percentage of managers with secondary school certificates. The recruitment of young people who had completed secondary school was both a choice of individual cooperatives and the result of a Legacoop campaign (Battilani 1999; Interviews with Valeriano Masotti and Luciano Sita). In fact, in the early fifties Legacoop started a program designed to spread accounting skills and methods among its associates, and to encourage accountants to join the co-operatives and the co-operative federations. Therefore, accountants, surveyors and agronomists were appointed in Italian cooperatives and one decade later a new generation of executives emerged among them. During the seventies and the early eighties, they led the introduction of many organizational and accounting innovations within the largest co-operatives. But above all, they were the protagonists of the enlargement of Italian co-operatives.

We can report as an example the case of Conad, the Consortium of Italian retailers co-ops. In the seventies the latter was run by Luciano Sita, an accountant who had been recruited immediately after his diploma by a buying group associated to Conad (Mercurio). In the history of this consortium, 1975 is a watershed, because it marks the end of spontaneous growth and the beginning of a phase of planned growth of the entire network of the retailers' buying groups (Conad Archive, Comma 42, 1976). In that year, together with the National Association of Retailers Cooperatives (ANCD), Conad worked out a plan of mergers throughout the country in order to increase the average size of the existing buying groups. (Conad Archive, Comma 57, 1977; Comma 77, 1979). Mergers continued without interruption during the eighties and contributed to the creation of a system of "market oriented co-operatives" of middle and large size (Conad Archive, Annual report 1977-1986). 
The generation of accountants, surveyors and agronomists brought a truly entrepreneurial culture within the co-operative movement, even if this didn't spread evenly in all sectors. While consumer and food processing co-operatives led the process of renewal, the agricultural ones failed to follow suit. Little by little, the entry of new generations of managers created a new co-operative culture based on a unique blend of market logic and the former anti-capitalistic culture, as expressed by communist ideology or by a section of the Catholic world. It is clear that by the end of the 1950 s, within the "red" co-operative movement there was already a desire for growth and expansion, for the capitalization of co-operative enterprises and for the creation of networks and consortia. But this desire seemed often in contrast with the values and ideals upon which the movement had been founded. In the end, the socialist/communist brand of co-operative enterprises, as represented by Legacoop, was forced to compromise on the principle of equality in order to introduce a more meritocratic approach to the remuneration of labour, and to overcome worker-based outlooks in order to create more room within co-operative administration for technicians and managers. This path, which was embraced between the 1950s and 1960s, was based on two beliefs: first, that successful cooperatives had to be created and managed in order to confirm the ideals of the cooperative movement; second, that the co-operative movement's task was to create large-scale cooperative enterprises capable of beating the capitalist monopolies present in the Italian market of the time.

Even if in our essay we don't deal with the transformation of co-operatives which belonged to the Catholic umbrella organization, it is worth mentioning that they also showed an interesting change during this period. In the Catholic world, the emphasis upon family had always implied a lesser importance being placed upon the 
individual. In the nineteenth century, this vision materialized in the form of restrictions upon the membership of cooperatives: for example, the by-laws of many of the local cooperative banks provided for the membership of the head of the family only, or excluded women from the co-operative. During the years following the Second World War, the focus on the family was particularly clear in the farming sector, where Catholic co-operation expressed a clear preference for 'collective family ownership', and where the head of the family continued to be the prominent figure, as the owner of both his own labour and of that of his family members, and thus was considered as having a right to remuneration for his own labour and for that of his family members. This vision of the family, in which only the head of the family was granted full socioeconomic recognition, was to be abandoned gradually, as other members of the family became increasingly visible from both the economic and the social point of view. Agricultural cooperatives were gradually replaced by food processing cooperatives, the members of which were now individual peasant farmers, regardless of their family ties, gender or status.

As a consequence of the mergers wave we mentioned above, since the seventies and even more in the eighties several large size co-operatives emerged; all of them required complex managerial skills. It was at this stage that the third generation of managers, those born at the turn of the forties and fifties, became active; with it we have the first massive entry of graduates, usually soon after graduation. They develop their careers fully within the cooperative movement, sometimes employed by the same enterprise, in other cases through vertical mobility that allows them to be recruited by larger size undertakings or by the umbrella federation. In services, mobility, through which these generation built their career paths, also includes Trade unions, because the 
social skills they acquired in such organizations were found of value for the enterprise, above all in the human resource management function. Usually graduates took leading positions within the managerial hierarchy since the late eighties.

Once again it is easy to identify a clear strategy by Legacoop, which, by stimulating the recruitment of graduates, tried to increase the level of formal training of future leaders. The process was particularly apparent in well established co-operatives, because they had already defined their managerial hierarchy. For instance, in the Alleanza Cooperativa Modenese (today Coop Estense, one of the nine large consumer co-ops) since the late seventies more than $60 \%$ of managers were graduate (Battilani 1999). Usually, they were recruited as white collars or mid-level managers, but sometimes (above all in co-operative facing some kind of difficulty) they were immediately entrusted with leadership roles.

However, some sectors stayed behind. Often in the newly formed co-operatives the educational profile of both members and executives was lower. During the seventies there was a new wave of services co-operatives coming into being. The most dynamic sectors were cleaning and transport. The founding members of the new co-operatives were cleaners, porters, truckers and so on. Usually they were founded by men and women from lower classes and with low levels of schooling. In these undertakings, managers often shared the social backgrounds and the formal education of members. An example of this type of situation comes from the history of the Food transport cooperative (Cta) which was founded in 1977 by 28 truck drivers, average age 34 years, most with only primary school, without money and in many cases even without trucks. The first president, Bartolini, born in 1941, was of the same age of the other members and could not afford to continue his education after primary school. (Interview with 
Bartolini).

The third generation of co-operative managers, regardless of its formal education, is very different from the previous one in terms of vision. Their shared experience is no longer the Resistance, but the epic of 1968, interpreted in at least two ways, as it emerges from the interviews: on the one hand the protest and the political commitment to social progress, on the other hand the commitment to acquire a university degree. For many of them to get a degree was a priority, because they wanted to reward their family for the sacrifices made to send them to school. Generally, their families of origin belonged to the lower-middle strata of society: sharecroppers, proletariat or urban underclass. For them, co-operation is both a secure job and an opportunity for social mobility. With the arrival of graduates, the corporate culture of co-ops changed deeply, little by little. The major changes began to be seen in the late eighties and early nineties, especially in the larger co-ops. Among the many, three changes were of particular importance: the adoption of a multidivisional organization, the introduction of differential wages for executives and low/mid-level managers and connected to this the narrowing of wage differentials between co-operative and IOE managers.

Once again the umbrella organization played a crucial role. In the mid-eighties Legacoop addressed the problem of giving greater transparency to the remuneration of executives. A survey conducted in 1988 by Corum (the consulting company set up in 1987 by the Modena provincial branch of Legacoop) revealed that co-operatives paid their middle managers lower salaries than those prevailing in private companies, and that the same was true when it came to senior management. On top of this, there was no discontinuity in the promotion from employee to executive. Finally, the variable wage 
components connected with incentives and premia was missing (Coind Archive, mimeo).

The solution was found with the importation of the Hay job evaluation scheme from the Anglo-Saxon countries. According to this model, company positions and rewards were classified according to the importance of the duties performed ${ }^{7}$. In this way, the rewards were differentiated on the basis of an objective criterion, and more precisely on the basis of the tasks and responsibilities of each manager or white collar workers. The change was driven by consulting companies. As a matter of fact, in the late eighties many provincial branches of Legacoop fostered the setting up of consulting companies, like Corum (in 1986) and Smaer (in 1985) in Emilia Romagna, which could buy the rights of the Hay method for Italy and help in the application of it among co-operatives by offering consultant services.

To better understand how this transformation emerged we will mention the case of COIND (a small co-operative producing food and chemical goods) in the mid-nineties. As stated by the President of the time:

"the problem arose from the fact that every time we tried to appoint from the market a new manager, we had to give him a larger salary compared with those who were already working with us. This was a very embarrassing situation. At one point it seemed appropriate to raise our executives and white collars wages. (Interview with Vincenzo Alberti).

Following the suggestions of Corum consultants and consequently adopting the Hay scheme, white collars and managers were divided into different groups and a

\footnotetext{
7 The Hay Guide Chart Profile System had been developed in the United States in the periods immediately before and after the Second World War. It was designed specifically to cover administrative and managerial jobs in large organizations. Hay was first used in the UK financial sector, then applied also to many other sectors. The scheme was amended in the late 1990s to accommodate local government manual jobs.
} 
correspondence between tasks and remuneration was fixed. On average, wages increased by 300 euro per month (Coind Archive). At the same time, part of the executives remuneration was linked to the co-operative performance. The co-operative chose a group incentive payment scheme to avoid negative effects on the business climate and internal co-operation ${ }^{8}$. (Interview with Luigino Franco). At the end of the process, the share of the cost of white collars and executives over the total cost of labour increased from $18 \%$ in 1995 to $26 \%$ in 1999. (Coind Archive, Human resource deparment).

The managers remuneration issue should be placed in a wider context of cooperative organizational renewal, which required the creation of appropriate managerial hierarchies. During the eighties, following, once again, the suggestions of consulting companies, many large co-operatives started to organize their managerial hierarchy according to the multi-divisional structure. This was the case for instance of Camst, Granarolo and Coind. Results were not always positive straight away, because in some cases the organizational transformation led co-operatives to excessively increase the number of managers and white collar workers, but subsequently they rationalized.

All these changes gave rise to an interesting innovation that began to emerge in the late nineties, namely the recruitment of executives from private companies. The similar remuneration, the disappearance of the antagonistic vision of co-operation and the greater uniformity in business practices created the conditions for a more frequent passage of executives from the private sector to the co-operative sector and vice versa. It is at this last stage that a problem of cooperative identity emerges. It could be possibile to talk about a fourth generation of cooperative managers with a very good formal education but not fully aware of the co-operative specific commitments and 8 Ibidem 
skills.

\section{Selected case studies}

In this section, we offer three case studies of major co-operatives, that show that the process we have modelized above was not so linear and was carried through with great discussions and some tensions. The first case deals with a construction co-op created in Ravenna in 1901 by bricklayers, CMC Cooperativa Muratori e Cementisti, (V. Zamagni, 2011). The co-op rapidly became large, but soon split into two co-ops as a result of ideological divisions (socialists on the one side, liberals on the other). Forcefully merged again during fascism $\mathrm{CMC}$ was reorganized in the years immediately following the end of World War II under the hegemony of communist members, not without major ideological conflicts with the socialist and liberal members who remained inside the co-op ${ }^{9}$. In the 1950s still, the co-op was made up of bricklayers and it was forbidden to accept as members white collar workers. Engineers when needed were appointed as consultants, whereas some surveyors were employees of the co-op. The size of the co-op at that time was around 1,500 workers, of which 1,000 members (all bricklayers), and activities were conducted in a very informal way. The first important decision taken was that of formalizing the organization of the co-op with a new statute approved in 1960, which among other things determined roles and tasks of middle rank managers, reintroduced the director general and expressed a preference for higher level managers to hold a university degree or at least a secondary school certificate.

These decisions allowed the strategies of the co-op to become more aggressive and, above all, new markets could be tapped. First, CMC engaged in the construction of silos

\footnotetext{
${ }^{9}$ Some of these left and created another construction co-op, ACMAR, still active at present.
} 
with a new technique coming from Sweden; next it entered the buoyant market of motorways and dams, plus the building of industrial plants (with special attention to electrical and ecological plants), of large residential quarters and of high quality public buildings. It next developed expertise in the construction of channels for undergrounds, high speed trains, deviation of rivers, construction of canals. CMC became a general contractor.

This meant a vast increase in capital investment, the use of prefabs and the need of many more blue collar workers, who could no longer be considered a marginal component of the co-op. A heated discussion brought in 1972 to the admission of blue collar workers as members, while between the end of the 1970s and the beginning of the 1980s the problem of remuneration of managers was faced, recognizing their different role inside the company and overcoming the old egalitarian approach ${ }^{10}$. In 1981 the first president who was not a bricklayer, but an accountant, was elected and an engineer became director general. The opening up of $\mathrm{CMC}$ to international activities was inaugurated in the mid-seventies, when director general was still a surveyor and many middle rank managers were self made bricklayers, but it was later carried on all over the world (mostly in the Middle East, Africa and Asia) by people with a university degree. Increasingly, both in Italy and abroad, co-op members came to play the role of project designers and directors of works, with a high level of human capital, making use of local bricklayers wherever they win a tender, appointed for the period of completion of the work. Today CMC has a turnover of 800 million Euros, about 8,500 employees

\footnotetext{
${ }^{10}$ Before the 1984 agreement, what was done was to grant to the blue collar workers an additional sum on top of the standard pay for skilled workers. After 1984, in any case, remuneration of managers in CMC has never reached capitalist levels.
} 
around the world, but only 500 of them are tenured, of which 373 are members of the co-op.

The successful managerialization of CMC was suffered inside the co-op and outside it in the co-operative movement as a process that would decrease the level of selfgovernance by the part of members. Memorable fights were taking place in the general assembly, in the board of directors meetings and in public discussions to keep control over managers by the part of members. The solution, which had to be found empirically, was the setting up of committees of members that should be consulted at all levels before decisions were taken by managers. In the end, it worked, and in $2011,110^{\text {th }}$ anniversary of the CMC, it can be said that this is one of the most successful examples of a co-op capable at the same time of competing nationally and internationally on a par with capitalist organizations, while having a different ownership structure and practicing a governance based on economic democracy.

A second example comes from Bologna and deals with a catering co-op, CAMST, which is the largest Italian company in the field, competing with French multinationals. CAMST was created the $16^{\text {th }}$ June 1945 by 16 waiters, cooks and barmen, to face the severe unemployment existing at the end of the war (Camst, 2002). Various restaurants, (mostly self service), snack bars and bars were soon opened up, the most famous of which was the snack bar-self service restaurant at the Bologna railways station, which served people from all over Italy and from abroad ${ }^{11}$. In the 1960 s Camst entered the business of catering inside exposition premises and of banqueting; in the 1970s it started catering for schools, hospitals, companies and other communities. In the same 1970s Camst branched out in other areas of Northern and Central Italy, directly or through the acquisition of other co-ops or joint stock companies, trying also to explore foreign

\footnotetext{
${ }^{11}$ Bologna is an important railways hub.
} 
locations (Croatia and Germany). It next promoted the diffusion of meal vouchers in Italy and more recently, it is developing gastronomy for large scale retail chains, networking especially with the two COOP and CONAD local chains. Camst today is a group of 20 companies, some of them joint stock companies controlled by the co-op, with a turnover of around 900 million Euros, more than 11,000 employees and more than 6000 members.

Unlike CMC, which chose over time to leave manual workers outside the structure of the co-op, given the temporary life of their construction sites, CAMST has been able to keep them inside, because of the stability of their employment over time, but the strategic decisions taken in the 1970s to move out of simple restaurant activities and manage preparation of meals for large communities entailed the decision to strongly managerialize the co-op. Already in the 1950s CAMST employed a number of accountants with a secondary school degree, who had put in place a detailed budget control of each point of sale. In the early sixties the accounts were mechanized thanks to the electronic devise Mercator by Olivetti and a detailed cost analysis was introduced. During the seventies, the attention was focused on the organizational structure, with the creation of the first managerial hierarchy. In 1974 a functional organizational structure was put in place with two distinct departments (accountancy and production); moreover, a separate division was set up for coordinating and managing travel agencies. The multifunctional organization was substantially kept until the mid-eighties, when the expansion into new geographical areas stimulated the adoption of the multidivisional form. More precisely, in 1984 three divisions were set up using an approach which mixed geographical and sectoral dimensions. This structure was particularly effective in assisting the co-op expansion, because usually mergers and acquisitions of companies 
and other co-ops gave birth to new territorial divisions. Of course, every time the organizational structure was changed, new managerial skills needed to be inserted, something that was done in a timely way.

We move now to the consideration of consumer co-ops. As mentioned in section 1, the COOP chain is the most important group acting in large scale retailing in Italy. In 2010 it is made up of 115 co-ops, with 7.5 million members, 1,444 points of sale (of which 100 hypermarkets). Nine of the 115 co-ops are very large, accounting for $92 \%$ of total turnover (which amounts to 13 billion Euros, $18.3 \%$ of market share). (V. Zamagni, P. Battilani, A. Casali, 2004). One of the nine major co-ops, UNICOOP TIRRENO, is under scrutiny today by one of the authors of the present paper, with the aim of analyzing its latest less than satisfactory performance. The opportunity is particularly welcome to discuss here the issue of managerialization in a not entirely successful case.

UNICOOP TIRRENO was born in 1945 in Piombino (Tuscany) with the name LA PROLETARIA $^{12}$ as one of the numberless consumer co-ops created in Tuscany, where there was a very widespread direct participation of common people into their co-op shops, existing in cities as well as in the very many small villages of the country side. As economic development touched upon Tuscany during the economic miracle and beyond, some of these co-ops developed into more substantial companies, taking over the shops of the less dynamic co-ops. LA PROLETARIA, which was one of the largest local co-ops, happened in the 1970s to acquire as a budget controller an accountant with a secondary degree who was very intelligent and capable ${ }^{13}$. He first strengthened the co-

\footnotetext{
${ }^{12}$ It was created by the steel workers of the Piombino factory, hence the name "The Proletarian".

${ }^{13} \mathrm{He}$ complained in the interview he granted to Vera Zamagni of never having been recognized formally as "director general", as a result of the egalitarian ideology prevailing inside that co-op.
} 
op along the coast of Tuscany ${ }^{14}$ concentrating a number of the small shops acquired into supermarkets and then he conceived the idea of enlarging the co-op outside Tuscany, first in Latium and next in Campania, with the support of the national association ANCC, which considered positively the diffusion of consumer co-ops in the South of Italy.

Both new regions were entirely different in terms of consumer co-op tradition, Latium showing a weak propensity to support co-ops and Campania an almost non existing one. Therefor, in most cases the new points of sale (often hypermarkets) were top down rather than bottom up decisions and could neither count on collaboration from local members nor on indication of suitable locations. On top of this, the inner organization of LA PROLETARIA, which in 1990 changed its name in COOP TOSCANA LAZIO, was ill suited to plan such a major development in unknown areas. The few existing managers were very local, the points of sale were all smallish, the chairmen of the co-op used to consider their appointments as non operative, the strong man of the co-op acting almost in isolation and on the basis of his personal contacts.

In 1996 this unsatisfactory state of affairs started to be under attack and in 1997 the management was changed, but major decisions about new locations for hypermarkets in Latium and in Campania had already been taken, underestimating the big jump from managing local small size shops in areas where co-operation was spontaneous and having to support big structures as the hypermarkets in places that had never been accustomed to the co-op presence and that, like Campania, even showed aversion against a co-op seen as a factor of disturbance of the existing economic "order" 15 . The new management, although better equipped than the previous one, felt inadequate and

\footnotetext{
${ }^{14}$ Florence and Siena are under see the presence of another co-op, which is the largest in Italy, UNICOOP FIRENZE.
} 
started to lean on consultants, appointing as a director of the hypermarket joint stock company created on purpose somebody who had run a capitalist premise and had never worked in co-ops. Efficiency improved, but none of the real problems of the co-op mostly wrong locations and inadequate specialization in running large premises - was solved, while the co-op identity suffered deeply and the budget turned into the red. After a few years, the learning process by the part of co-op managers went far enough to be able to master the situation. The name of the co-op was changed in 2004 into UNICOOP TIRRENO, un-co-operative managers were dismissed, some of the worst locations were sold out, other mergers were arranged with local small consumer co-ops, synergies and specificities of the various different activities were re-arranged; the co-op is now on its way back to equilibrium, running in 2010110 points of sale, among which seven hypermarkets, with 850.000 members and a turnover of 1.2 billion Euros.

How was it possible to redress the situation? The umbrella organization Legacoop with its sectoral association ANCC was helpful in advising, in showing management models (employed in other more successful large consumer co-ops) and in lobbying when necessary with various institutions, but above all the co-op enjoyed the support of the members of its Tuscan cradle, who willingly deposited their savings with the co$\mathrm{op}^{16}$, supplying an important source of liquidity for investments. Also, the managers who directed the co-op since 1997 were thoroughly dedicated to their company and

\footnotetext{
${ }^{15}$ One of the IPERCOOP TIRRENO hypermarkets in Campania had to be closed down twice, because of pretentious administrative problems raised by the local "camorra" affiliates. Another hyper could open up only after the entire city council of the place was removed from office and the city politics was put under a government commissioner.

${ }^{16}$ It must be noted that the Italian legislation allows co-ops (not only consumer co-ops) to attract deposits up to a fixed amount, with a remuneration at a premium with comparison to market rates, to be used to finance co-ops development plans.
} 
determined to come to terms with the problems; though they still made mistakes, they learned from them and encouraged younger generations to strengthen their professional background, while remaining fully aware of co-operative principles.

\section{Final remarks}

In conclusion we would like to offer some broader consideration. In a recent paper Franco Amatori skeched the typologies of entrepreneurs that emerged from the history of industrial Italy (Amatori 2011). Even if in his essay he doesn't take into consideration co-operative managers, it is worth asking where they can be situated in his typology. From many points of view, co-op managers can be considered similar to the entrepreneurs operating in the "industrial districts". This is true above all for the first generation of co-operative managers. However, because co-operatives don't face the traditional constraints to growth encountered by family firms, the successive generations of co-op managers could more easily enlarge the enterprises they ran. Indeed, over the last two decades some big and innovative enterprises have emerged from the myriads of co-operatives. Paradoxically, we can conclude by saying that the managers of the biggest co-operative groups have been in the last decades the best example of market-oriented entrepreneurs in Italy, what Amatori calls the "Milanese" typology of entrepreneur.

This leads us to a second remark, namely the organizational isomorphism of cooperatives. According to some contributions, co-operatives couldn't avoid starting an isomorphic trend, though often non congruent to their inner identity, because they aimed at getting legitimacy from society, from markets and from financial institutions. (Hawley 1968, Meyer 1979 and Fennell 1980). According to Meyer (1979), the need for 
efficiency and competition is the driving force of organizational innovation and explains the growing homogeneity of organizations. Can we say that the modernization of Italian co-operatives has been an example of institutional isomorphism?. To be able to answer this question, it is helpful to reflect on the material gathered in this essay. Managerial skills have always been crucial for the success of co-operative undertakings as they were for IOEs. However, historically this problem has been particularly pressing for coops, because they have been a vehicle for the "have-nots" to improve their standards of living through organized self-aid. As a consequence, many co-ops have been set up by low income people without formal education. This is why in the seventies and eighties when the viability of co-ops became an important issue, the attention of many scholars focussed on the lack of managerial skills. In many countries the co-operative movement became aware of this weakness rather early. The Italian cooperative umbrella organizations where at the forefront, so that since the fifties they stimulated the enrolment of employees with secondary school certificates. The acquisition of new managerial skills came from the entry of young people, rather than from appointing senior IOE managers from the outside. However, the Italian umbrella organizations never tried to imitate the English experience of the Co-operative College and preferred to rely on the courses of study offered by the Italian public schools and eventually on master courses organized by some prestigious private universities. In the eighties, even a scent of America started to spread among co-operative executives, with the adoption of the Hay scheme.

In most dynamic co-operatives the modernization of both the organizational structures and accountancy required no more than two decades. It started certainly later than in the largest Italian corporations of the time, but in many cases it anticipated the 
updating in middle size companies. Overall, the creation of managerial hierarchies and the modernization process forced co-operative enterprises to compromise on some values. For instance, the leftist part of the movement had to accept the mitigation of the equality principle in order to introduce a more meritocratic approach to the remuneration of labour.

However, the adoption of models developed by IOE enterprises has not been so passive. All the generations of managers we considered were aware of the co-operative specific commitments and skills. In some cases, the co-operative identity was turned into a strength, in other cases it influenced the organizational form. Suffice it to recall here the marketing strategy of Granarolo. We can also point out that in the construction of multifunctional or multi-divisional organizational structures the relationship with members and the management of human resources were assigned a strategic role. Usually, these functions were not confined into a department but remained the responsibility of top managers. We can therefore say that the organizational form confirmed the crucial role of workers and members in the co-operative enterprise. What emerged at the end was an original mix of market oriented attitude and co-operative values.

Nevertheless, at the end of all these changes a problem of co-operative identity did emerge, without leading to demutualization for a variety of reasons. The legislation up to 2003 prevented demutualization and even after 2003 made it difficult, because the new demutualized company cannot carry with it the capital accumulated by the predecessor co-op as indivisible assets ${ }^{17}$. On top of this, most of the managers even today have a career inside the co-operative movement (often moving from one company

\footnotetext{
${ }^{17}$ In case of demutualization, indivisibile assets must be conferred to the umbrella organizations for the development of co-ops activities.
} 
to another), which induces them to be attuned with the co-operative identity of companies. Finally, the strong leadership by the umbrella organization Legacoop, which spread best practices and helped overcoming crisis situations, is also helpful for the preservation of co-operative values.

It is however fair to say that the problem of coherence with their co-operative identity of co-operative groups having many joint stock companies inside the group is not entirely overcome. If Italian co-operatives want to continue their life as cooperatives, they need to envisage a cultural renewal and support the revision of cooperative principles in the present day context with investments in research and education. 


\section{REFERENCES}

Alchian A. and H. Demsetz (1972), "Production, information costs, and economic organization", American Economic Review, 62, December, pp. 777-795

Amatori F. (2011), Entrepreneurial Typologies in the History of Industrial Italy: Reconsiderations. Business History Review, 85, pp. 151-180.

Battilani, P. (1999), La creazione di una impresa moderna, Bologna, Il Mulino

Battilani P. (2011), Il gruppo Coind: storia di un co-packer, Bologna, il Mulino

Battilani P. and G. Bertagnoni, (2010), Cooperation, Networks, Service: Innovation in outsourcing, Preston, Crucible.

Battilani P. and H. Schroeter (2011), Demutualisation and its problems, forthcoming

Battilani P. and V. Zamagni (2010), “Co-operatives (1951-2001)”, in Forms of Enterprise in 20th Century Italy, ed. A. Colli and M. Vasta. Cheltenham: Elgar, pp. 273-293

Battilani P. Bertagnoni G. e Vignini S. (2008), Un'impresa di cooperatori, artigiani, camionisti. La Cta e il trasporto merci in Italia, Bologna, Il Mulino

Bertagnoni G. (2002), Uomini, donne, valori alle radici di Camst, Bologna, Il Mulino.

Bertagnoni, G. (ed.) (2004), Una storia di qualità. Il gruppo Granarolo fra valori etici e logiche di mercato, Bologna, il Mulino.

Bettin G. (1999), Sul concetto di generazione politica, in Rivista italiana di scienza politica, 1.

“Il "Bilancio" di un'Assemblea" (1977), “COMMA”, periodico di informazione del Consorzio Nazionale Dettaglianti, no. 57.

Camst: ristorazione e socialità (2002), ed. V. Zamagni, Bologna: Il Mulino

Cook J., Deakin S. and Hughes A. (2001), “ Mutuality and Corporate Governance: The Evolution of UK Building Societies Following Deregulation", Working Paper 205, ESCR Center for Business Research, University of Cambridge, June 
Develtere P. and I. Pollet and F. Wanyama (2009), L'afrique solidaire et entrepreneurial, Bureau international du Travail, Institut de la Banque mondiale

Di Marco F. (1956), "Uno schema di bilancio preventivo per le cooperative di consumo", Cooperazione italiana, 22, February, pp.

Fabbri, F. (1995), Da birocciai a imprenditori. Una strada lunga 80 anni. Storia del consorzio cooperative costruzioni, Milan, Angeli

Fennell, M. L. (1980) "The effects of environmental characteristics on the structure of hospital clusters." Administrative Science Quarterly, 25, pp.484-510

Gherpelli I. (1956), "Il piano dei conti”, Cooperazione italiana, 7 March 1956.

Griffith, D. (2003), What is a cooperative manager?, Co-operative Federation of Victoria.

Hawley, A. (1968), "Human ecology”, pp. 328-37 in: David L. Sills (ed.), International Encyclopedia of the Social Sciences, New York: Macmillan

Hueth, B., and Marcoul, P., (2008), "Incentive Pay for CEOs" , Cooperative Firms, 17, available at SSRN: http://ssrn.com/abstract=1303050

Hind A. M (1999), "Co-operative life cycle and goals", Journal of Agricultural economics, 50,3, pp.536-548.

Hind A. M (1999), “Co-operative life cycle and goals”, Journal of Agricultural economics, 50, 3, pp.536-548

Jan T.R., M. Trehan and R. Trehan (2009-2010), Indian Business and Economics, Star Offset: Delhi.

Leonardi, A. (2005), Collaborare per competere. Il percorso imprenditoriale delle Cantine Mezzacorona, Bologna, il Mulino

Mannheim K. (1952), On the problem of generations, in Collected Works of Karl Mannheim, v. 5, Routledge, London 
Menzani T. and V. Zamagni (2010), “Cooperative networks in the Italian economy", Enterprise and Society, XI, march, no.1, pp. 98-127

Meyer, J.W. (1979), The impact of the centralization of educational funding and control on state and local organizational governance, Stanford, CA: Institute for Research on Educational Finance and Governance, Stanford University, Program Report No. 79-B20

Mayers, D. and Clifford. W. Smith., (1986), 'Ownership structure and control: the mutualization of stock life insurance companies', Journal of Financial Economics, 16, pp.73-98.

"Nasce il Mercurio Romagnolo" (1976) COMMA, periodico di informazione del Consorzio Nazionale Dettaglianti, no. 42

Nkhoma A. and D. Conforte (2011), Unsustainable cooperatives: lessons from Malawi, IFAMA Symposium, Frankfurt

Ortoleva P. and M.T. Di Marco, (2004), Fare marketing con la simpatia della gente». La presenza pubblica della Granarolo negli anni del miracolo economico, in Bertagnoni 2004.

"Produzione e Commercio" (1979), COMMA, periodico di informazione del Consorzio Nazionale Dettaglianti, no. 77

Ryder N. e Charles F. Westoff, (1971), Reproduction in the United States 1965, Princeton, Princeton University Press.

Rothschild-Whitt $J$. (1979), "The collectivist organization: An alternative to rational bureaucratic models", American Sociological Review, 44, 509-527

Satgar V. and M. Williams (2008), The Passion of the people, Co-operative and Policy Alternative Center (COPAC) 
Stephens, M (2001) "Building Society Demutualization in the UK", Housing Studies, 16 (3) $335-352$

Tayler G. (2003), "UK building society demutualization motives, Business Ethics", European Review, 12 , no.4, October, pp.....

Thirkell, J.D. (1989), “Attracting and Motivating Managers in U.K. Agricultural Cooperatives", Yearbook of Cooperative Enterprise, Oxford: Plunkett Foundation.

Trechter, D.D., R.P. King, D.W. Cobia, and J. G. Hartell (1997), "Case Studies of Executive Compensation in Agricultural Cooperatives”, Review of Agricultural Economics, 19 (2), 492-503.

Zamagni V. (2007), "Italy's cooperatives from marginality to success", in Cooperatives in $21^{\text {st }}$ century. The road ahead, ed. S. Rajagopalan, Punjagutta: Icfai University Press, pp. $155-79$.

Zamagni V. (2011), Da Ravenna al mondo. Come la CMC è diventata una grande cooperativa internazionale (1952-1985). Bologna: Il Mulino

Zamagni V., P. Battilani and A. Casali (2004), La cooperazione di consumo in Italia. Centocinquant'anni della Coop consumatori: dal primo spaccio a leader della moderna distribuzione. Bologna: Il Mulino.

Zamagni S. and V. Zamagni (2010), Cooperative Enterprise. Facing the Challenge of Globalization. Cheltenham: Elgar

\section{Archives}

National Association of Retailer Co-operatives (ANCD) Archive, Progetti di fusione fra $i$ gruppi associati, Direzione Organizzazione e Sviluppo, May 1975

Conad Archive, Annual report 1977-1986 
Coind Archive, Corum, Indagine conoscitiva e sulle dinamiche organizzative delle imprese cooperative, mimeo 1988.

National Association of Consumer Co-operatives Archive, Direzione del 29 novembre 1984

Co.ind Archive, Human Resource Department, White collar and manger remuneration, 1999.

Camst Archive, Programmazione in Camst. Proposte di lavoro per il Piano Programma Triennale '85-'87.

Camst Archive, Bozza di riorganizzazione aziendale, September 1984.

Camst Archive Mansionario discusso nel marzo 1974

Camst Archive, Annual Reports, 1970-1989

Granarolo Archive, Minutes of the Board of Directors

\section{Interviews with}

Luigino Franco, Co.ind human resource manager, recorded by Patrizia Battilani March 1999

Vincenzo Alberti, Coind president, recorded by Patrizia Battilani November 2010

Franco Migliori; recorded by Patrizia Battilani February 1999

Valeriano Masotti, recorded by Patrizia Battilani, March 1999.

Luciano Sita recorded by Patrizia Battilani, March 1999.

Luciano Bartolini, recorded by Patrizia Battilani September 2006 


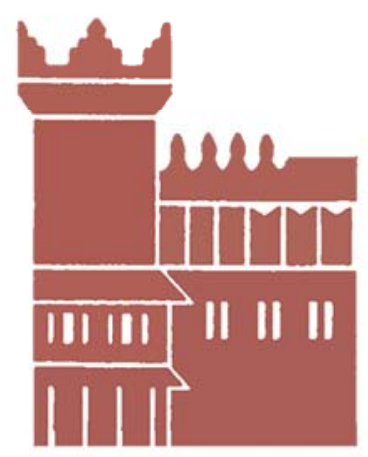

Alma Mater Studiorum - Università di Bologna DEPARTMENT OF ECONOMICS

Strada Maggiore 45

40125 Bologna - Italy

Tel. +39051 2092604

Fax +390512092664

http://www.dse.unibo.it 